\title{
"GOOD MORAL CHARACTER" AS A PREREQUISITE TO ADMISSION TO THE BAR: INFERENCES TO BE DRAWN FROM PAST ACTS AND PRIOR MEMBERSHIP IN THE COMMUNIST PARTY*
}

To PROTECT clients from unethical and unskilled attorneys, and to assure the judiciary of a trustworthy bar, courts have traditionally exercised the power to exclude incompetent and unprincipled persons from the legal profession by means of admission and disbarment procedures. ${ }^{1}$ Because exclusion seems a more serious deprivation after an individual has established himself in the profession, the substantive and procedural requirements necessary to establish questionable moral character for disbarment purposes are stricter than those applicable to the admission process. ${ }^{2}$ Disbarment proceedings can be brought only for specific acts of misconduct that are considered inimical to the interests of client and court, ${ }^{3}$ whereas admission may be denied for character deficiencies

SSchware v. Board of Bar Examiners, 291 P.2d 607 (N.M. 1955).

1. Thus admission may be denied for lack of legal knowledge, e.g., Mitchell v. State Board of Law Examiners, 155 Mich. 452, 119 N.W. 587 (1909) ; In re Myles, 64 Nev. 217, 180 P.2d 99 (1947), or for failure to show good moral character, e.g., Spears v. State Bar, 211 Cal. 183, 294 Pac. 697 (1930) ; In re Farmer, 191 N.C. 235, 131 S.E. 661 (1926) ; In re Weinstein, 150 Ore. 1, 42 P.2d 744 (1935).

Similarly, practicing attorneys have been disciplined for incompetence, although punishment is rare and usually not severe. See, e.g., Trusty v. State Bar, 16 Cal. 2d 550, 107 P.2d 10 (1940); In re Franzino, 285 App. Div. 12, 135 N.Y.S.2d 11S (1st Dep't 1954); Note, The Impasition of Disciplinary Measures for the Misconduct of Attomeys, 52 Couvar. I. Rev. 1039, 1047 (1952). And attorneys have been disciplined for unethical conduct. See, c.g., People v. Logan, 272 P.2d 993 (Colo. 1954) ; Fairfield County Bar v. Taylor, 60 Conn. 11, 22 A.tl. 441 (1891); In re Casey, 359 Ill. 496, 195 N.E. 39 (1935); In re Richter, 187 Wis. 490,204 N.W. 492 (1925).

This Note deals primarily with the character qualifications necessary for admission to the bar. In addition to possessing a good moral character, applicants must generally satisfy requirements of residence, skill, citizenship and age. See, e.g., CAL. Bus. \& Prof. CodE $\$ 6060$ (1955); Sunvey of the Legal Profession, Reports of Consultant and The Auvisory and Editorial Conartitee on Bar Examinations and Requirenients for AdrIISSION to THE BAR 100-08 (1952) (hereinafter cited as REPORT oN REQUIREMENTS for AdMisston to the $B A R)$.

2. E.g., Spears v. State Bar, supra note 1, at 188,249 Pac. at 699 . See In re Wells, $174 \mathrm{Cal}$. 467, 474-75, $163 \mathrm{Pac} .657,660$ (1917), where the court indicated that evidence sufficient to warrant denial of admission might be insufficient to establish guilt for disbarment purposes. This distinction is often rationalized by denoting an established law practice as "property," while refusing to so label an applicant's interest in being admitted. See In re O'Brien's Petition, 79 Conn. 46, 55, 63 At1. 777, 780 (1906), discussed with approval in Starrs, Considerations On Deternination of Good Moral Character, 18 U. DET. L.J. 195, 225-26 (1955).

3. E.q., Exx parte Wall, 107 U.S. 265 (1882) (participation in mob-lynching of accused) : United States v. Costen, 38 Fed. 24 (C.C.D. Colo. 1889) (sale of confidential information to adverse parties) ; In re Meyerson, $190 \mathrm{Md}$. 671, 59 A.2d 489 (1948) (convicted 
inferred from generally questionable conduct over a long period of time.4 Similarly, in a disbarment proceeding the complainant has the burden of showing the attorney's unsuitability for continued practice, ${ }^{5}$ while an applicant for admission must affirmatively establish his good moral character. ${ }^{6}$ Moreover, conduct warranting denial of admission may be insufficient to support disbarment. $^{7}$

Since the objectives of both disbarment and admission proceedings are identical, ${ }^{8}$ the reasons for denying admission should be related, as are the grounds for disbarment, to the purposes of exclusion. 9 The courts have partially recognized this principle, stating that admission may not be denied arbitrarily ${ }^{10}$ or by unfair procedural means. ${ }^{11}$ Persons have been denied admission for nondisclosure of relevant information to character committees, ${ }^{12}$ or

of conspiracy to cause an abortion) ; State v. Palmer, 160 Neb. 786,71 N.W.2d 491 (1955) (manufacturing false evidence) ; In re Bennett, 201 Ore. 237, 269 P.2d 490 (1954) (conviction of larceny) ; In re O-, 74 Wis. 163, 42 N.W. 220 (1889) (misuse of confidential information).

4. E.g., In re Weinstein, 150 Ore. 1, 42 P.2d 744 (1935) (general reputation) ; In rc Wells, 174 Cal. 467, 163 Pac. 657 (1917) (history of defrauding creditors, of suggesting perjury, of questionable attempt to gain admission) ; In re Stover, 65 Cal. App. 622, 224 Pac. 771 (1924) (dice shark; record of arrests); In re Farmer, 191 N.C. 235, 131 S.E. 661 (1926) (history of questionable dealings).

5. E.g., In re Brown, 389 Ill. 516, 524, 59 N.E.2d 855, 858 (1945); In re Steiner, 199 La. 500, 508, 6 So. 2d 641, 643 (1942) ; In re Spencer, 206 App. Div. 806, 201 N.Y. Supp. 315, 318 (3d Dep't 1923) ; In re Disbarment Proceedings, 321 Pa. 81, 100, 184 Atl. 59,67 (1936). But where the accusation is admitted or the conduct is proved, the burden shifts to the attorney to justify his acts. In re Greer, 52 Ariz. 385, 393, 81 P.2d 96, 99 (1938); In re Barshay, 262 App. Div. 84, 28 N.Y.S.2d 50 (1st Dep't 1941).

6. E.g., Spears v. State Bar, 211 Cal. 183, 294 Pac. 697 (1930) ; Rosencranz v. Tidrington, 193 Ind. 472, 474, 141 N.E. 58,59 (1923) ; State ex rel. Board of Bar Examiners v. Poyntz, 152 Ore. 592, 595, 52 P.2d 1141, 1142 (1935).

7. In re Wells, 174 Cal. 467, 163 Pac. 657 (1917) ; In re Hyra, 15 N.J. 252, 104 A.2d 609 (1954) (failure to disclose prior convictions, which would have precluded admission, punished not by disbarment, but by a two-year suspension). Compare Sheiner v. Florida, 82 So. 2d 657 (Fla. 1955) (refusal to answer questions relating to present or past membership in the Communist Party deemed insufficient to warrant disbarment), with In rc Anastaplo, 3 Ill. 2d 471, 121 N.E.2d 826 (1954), appeal dismissed, 348 U.S. 946 (1955) (similar refusal justified denial of admission).

8. See text at notes 34-40 infra.

9. Cf. In re Rouss, 221 N.Y. 81, 85, 116 N.E. 782, 783 (1917).

10. Ex parte Garland, 71 U.S. (4 Wall.) 333 (1866) (test oath required of all candidates for admission to the bar bore no relation to the qualifications necessary for the profession) ; Dent v. West Virginia, 129 U.S. 114, 121-24 (1889) (due process of law is intended to secure a citizen against any arbitrary deprivation of his rights, and among these rights is the ability to follow any lawful business, calling or profession) (doctor) ; Smith v. Texas, 233 U.S. 630 (1914) (conductor) ; Noel v. People, 187 Ill. 587, 58 N.E. 616 (1900) (druggist) ; Wyeth v. Board of Health, 200 Mass. 474, 86 N.E. 925 (1909) (undertaker).

11. Goldsmith v. Board of Tax Appeals, 270 U.S. 117 (1926) ; Coleman v. Watts, 81 So. 2d 650 (Fla. 1955).

12. E.g., Carver v. Clephane, 137 F.2d 685 (D.C. Cir. 1943) (failure to disclose previous expulsion from administrative agency bar) ; Spears v. State Bar, 211 Cal. 183, 294 
for statements before such committees which indicated that the applicant might disregard certain ethical standards of the profession. ${ }^{13}$ And exclusion has resulted for commission of acts which were illegal at the time of commission, such as embezzlement, ${ }^{14}$ handling stolen property ${ }^{15}$ and forgery, ${ }^{16}$ notwithstanding absence of criminal convictions for those acts. A like result has been reached where the acts were improper although not illegal when performed, such as employment as a runner in an attorney's office. ${ }^{17}$ In these instances past conduct was utilized as evidence of present character deficiency for legal service, and of future inclination toward unethical behavior. Admission has also been denied where doubt existed as to present capacity of the applicant to take an oath to support the constitution, ${ }^{18}$ or where the applicant was found presently to espouse the violent overthrow of the government.19

In Scliware v. Board of Bar Eraminers, ${ }^{20}$ the New Mexico Supreme Court

Pac. 697 (1930) (failure to disclose arrests and criminal charges); In re Portnow, 253 App. Div. 395, 2 N.Y.S.2d 553 (2d Dep't 1938) (impersonation). See also In re Baldwin, 258 App. Div. 661, 17 N.Y.S.2d 727 (2d Dep't 1940) (revocation of license for misrepresentation on admission questionnaire). Revocation of a license to practice for nondisclosure of facts which would have been sufficient to preclude admission is not considered disbarment, even though the deprivation may be just as severe. See In re Klein, 242 App. Div. 494, 275 N.Y. Supp. 703 (1st Dep't 1934). Bui see In re Hyra, 15 N.J. 252, 104 A.2d 609 (1954).

13. See the decisions of the Philadelphia County Admission Committee, digested in Douglas, The Pcmsyliania System Governing Admission to the Bar, 54 A.B.A. REP. 701, 703-05 (1929), especially cases $6,7,10,13,19,23,29$.

14. Douglas, supra note 13, at 703, case S; In re Farmer, 191 N.C. 235, 131 S.E. 661 (1926).

15. Spears v. State Bar, 21 Cal. 183, 294 Pac. 697 (1930).

16. In re Dillingham, 1SS N.C. 162, 124 S.E. 130 (1924) (forgery, among other grounds) ; In $r e$ Garland, 219 Cal. 661, 28 P.2d 354 (1934) (same); In re Casablanca, 30 P.R. 368 (1922) (notwithstanding pardon) ; Douglas, supra note 13, at 705, case 46.

17. Douglas, supra note 13 , at $703-05$, cases $16 \& 31$; cf. id., case 24 (registered at Pennsylvania law school as New Jersey student to avoid Pennsylvania requirements) ; case 38 (associated in business with father who became bankrupt under questionable circumstances); In $r c$ Bowers, 138 Tenn. 662, 200 S.W. 821 (1918) (solicited business for an attorney).

18. In $r e$ Summers, 325 U.S. 561 (1945) (conscientious objector deemed unable to take oath to support state constitution in good faith) ; In re Anastaplo, 3 Ill. 2d 471, 121 N.E.2d 826 (1954), appeal dismissed, 348 U.S. 946 (1955) (refusal to say whether or not present member of Communist Party) ; cf. Cohen v. Wright, 22 Cal. 293 (1863) (failure to take oath).

19. Application of Cassidy, 268 App. Div. 282, 51 N.Y.S.2d 202 (2d Dep't 1944), aff'd, 296 N.Y. 926, 73 N.E.2d 41 (1947) ; cf. Martin v. Law Society, [1950] 3 D.L.R. 173 (B.C. C.A.) (acknowledged present membership in Communist Party but disavowed advocacy of force and violence) ; Konigsberg v. State Bar, (unreported decision of Supreme Court of California declining to review Board of Bar Examiners' refusal to certify applicant's good moral character for, inter alia, failure to sustain burden of proving he did not advocate overthrow of government by force and violence), petition for cert. filed, July 18, 1955, 24 U.S.L. WEEK 3054 (U.S. Sept. 13, 1955) (No. 244).

20. 291 P.2d 607 (N.M. 1955), 42 A.B.A.J. 352 (1956).

The court considered Schware's application within its original jurisdiction and denied 
went further than any prior decision in drawing inferences of unfitness. Schware was denied admission to the bar, despite undisputed evidence supporting his present good moral character, solely on the basis of long-past acts which were neither illegal nor, by general consensus, clearly improper when performed. Exhaustive and undisputed evidence in the form of character testimony, letters and statements showed that for a thirteen-year period Schware's moral character was unimpeachable. ${ }^{21}$ The court's denial of admission, however, was based on four types of past acts which were considered indicative of bad moral character: (1) In the thirties Schware had used aliases in order to gain employment and facilitate union organizational activities. ${ }^{22}$ (2) Schware had been arrested three times, twice in connection with the California maritime strike of 1934 and once on suspicion of possessing a stolen car. None of these apprehensions resulted in indictment or conviction. ${ }^{23}$ (3) Schware had been indicted under the Neutrality Act ${ }^{24}$ for recruiting volunteers for the

admission solely on facts furnished by the applicant. Schware v. Board of Bar Examiners, 291 P.2d 607, 608, 610 (N.M. 1955). Although the court stressed that the denial was a matter to be considered originally, it felt constrained to give weight to the Board of Bar Examiners' recommendations especially because the Board was "comprised of leaders of the legal profession in this state." Id. at 617. The weight to be attributed to Bar Examiner findings is essentially a matter of judicial discretion. Admission itself is within the "inherent powers" of the court. Brydonjack v. State Bar, 208 Cal. 439, 281 Pac. 1018 (1929). Hence a legislatively created Board of Bar Examiners has no direct power to admit or exclude. State ex rel. Laughlin v. Washington State Bar Ass'n, 26 Wash. 2d 914, 176 P.2d 301 (1947). Yet in most jurisdictions the legislature may prescribe the minimum standards required. In re Day, 181 IIl. 73, 54 N.E. 646 (1899) ; Opinion of the Justices, 279 Miass. 607,180 N.E. 725 (1932). And while determining whether the specific applicant meets the legislative or judicial standards is primarily a matter for the court, In re Day, supra; State ex rel. Ralston v. Turner, 141 Neb. 556, 4 N.W.2d 302 (1942), this determination can be delegated in large part to an investigatory committee created either by the legislature or by the court, and the committee's findings may be given great weight, In r $\varepsilon$ Frank, 293 Ill. 263, 127 N.E. 640 (1920) ; In re O'Brien's Petition, 79 Conn. 46, 63 Atl. 777 (1906) ; Mitchell v. Board of Law Examiners, 155 Mich. 452, 119 N.W. 587 (1909). One commentator characterizes the Board's status in Michigan as that of a special master. See Starrs, supra note 2, at 211.

21. More than twenty persons attested to Schware's good moral character, including his Rabbi, fellow students, law profe'ssors and a local attorney. Schware v. Board of Ear Examiners, 291 P.2d 607, 615, 618 (N.M. 1955). After marriage in 1944, he served with the United States Army overseas and upon discharge supported his wife and children while attending college and then law school. Id. at 614, 622. Schware also established an anonymous scholarship at the University of New Mexico Law School for needy students which he intended to continue indefinitely. Id. at 615 . See In re Stepsay, 15 Cal. 2d 71, 98 P.2d 489 (1940), where the court reversed the Bar Committee's denial of admission, stressing the weight to be attributed to letters from respectable references.

22. Schware v. Board of Bar Examiners, 291 P.2d 607, 611-12, 617 (N.M. 1955). See text at note 42 infra.

23. Schware v. Board of Bar Examiners, 291 P.2d 607, 612-13, 617. See text at notes 46-47 infra.

24. 18 U.S.C. $\$ 959$ (1952). 
Spanish Loyalists. The indictment was nol-prossed.25 (4) Most significant of all, in the court's view, Schware had been connected with the Communist Party for a seven-year period which ended when, in 1940, he repudiated all allegiance to it. ${ }^{26}$

As the dissent points out, the majority predicated the denial of admission solely on inferences drawn from acts committed more than thirteen years previously, despite uncontroverted evidence of good moral character in the interim. ${ }^{27}$ And the dissenting justice therefore seems correct in his conclusion that, since nothing can change the past acts on which the denial was based, it must be considered permanent. ${ }^{2 s}$ For there is nothing in the record which contradicts the completeness of Schware's break with the Communist Party. The majority seized upon a letter written in 1944 which contained statements deemed to reflect on the sincerity of Schware's conversion. ${ }^{28}$ But these statements at the most support the inference that Schware classed "anti-Communism," whatever that meant to him in 1944, with racial and religious prejudice. $^{30}$ And unless these views are tenable grounds for nonadmission to the

25. Schware v. Board of Bar Examiners, 291 P.2d 607, 613, 617 (N.M. 1955). See text at notes 50-51 infra.

26. Schware v. Board of Bar Examiners, 291 P.2d 607, 616, 617 (N.M. 1955). Although the court was unwilling to specify this as the only grounds for its decision, on motion for rehearing it reiterated that the affiliation was a prime consideration. Id. at 630 .

27. Id. at 629,635 .

28. Id. at 635-36. On motion for rehearing Schware asked whether he was forever barred from admission. The court refused to answer the question, stating that "the answers to such a request will depend upon the showing then made and how it may be viewed by the Court." Id. at 631 .

29. Id. at 616.

From a group of Schware's personal letters which he submitted to show his break with the Communist Party, one that he wrote while in the Army in 1944 was used by the majority to indicate a lack of sincerity in his rejection of the Party. In commenting to his wife on "Jim-Crowism" in the South, Schware wrote:

"Jim-Crow is on a par with Anti-Semitism, anti-Catholicism, anti-Comnntnism. In a democracy one cannot discriminate against a minority. When one does, consciously or unconciously they are playing Hitler's game, making use of his favorite tactic to divide us, certainly not contributing to National Unity which is so important not only for winning the war in the shortest period of time, but also for the winning of a just peace and making this world a better place to live in for all.

"All the above anti's I mentioned are most dangerous and stupid mistakes for Americans to make. They violate Christian ethics as well as all other ethical principles that recognize the brotherhood of man. To top it all off, consider them immoral." Ibid. (Emphasis added by the court.)

The court concluded from this passage that Schware "would still the voice of all who criticize Communism." Ibid. (Emphasis added.) Although the letter makes it clear that Schware retained a so called "liberal" philosophy, it does not support the majority opinion's thesis that Schware was praising Communists, and that he would attack all who opposed Communism. It does not seem that an inference of insincerity in Schware's break with the Party can properly be based on those two words in a twelve-year-old letter, especially in the face of overwhelming evidence of conduct inconsistent with Communist affiliation.

30. It is not clear from the letter just what Schware meant by listing "anti-Communists" among his dislikes. The term was even more ambiguous in 1944 than it currently is, and 
bar, the Schware case can be supported only if there is a reasonable relation between decade-old acts of the applicant and his present fitness to serve as a lawyer. ${ }^{31}$

In determining fitness for admission to the bar, state courts must meet the standard imposed by the due process clause of the Fourteenth Amendment. 32 The past acts of the applicant must bear a reasonable relation to the disqualification imposed, and inferences drawn from the facts presented may not be arbitrary or discriminatory. ${ }^{33}$ In assessing the reasonableness of the relation between past acts and moral unfitness for the bar, constant reference must be had to the purposes to be served by excluding the morally unfit. Good character is required of an applicant both to assure future clients that they may employ his services with confidence that their interests will be protected, ${ }^{34}$ and to guarantee that the candidate will not obstruct the administration of judicial

many manifestations of anti-Communism (e.g., congressional investigations) were regarded with abhorrence by large groups of Americans. See, e.g., ANrericar Civil Liberties Union Report, In Times of Challenge, U.S. Liberties, 1946-47, at 29-32 (1947) ; Carr, The House Comimittee on Un-American Activities 1945-1950, at 1-3, 452-63 (1952).

31. See notes 32, 33 infra and accompanying text.

32. Cf. Slochower v. Board of Higher Education, 76 Sup. Ct. 637, 639 (1956) ; Wieman v. Updegraff, 344 U.S. 183, 191 (1952) ; Schactman v. Dulles, 225 F.2d 938, 941, 943 (D.C. Cir. 1955).

The Fourteenth Amendment is applicable even if admission to the bar is considered only a "privilege." Many decisions identify the practice of law as a privilege. E.g., Petition for Integration of Bar of Minnesota, 216 Minn. 195, 200, 12 N.W.2d 515, 518 (1943) ; In re Rouss, 221 N.Y. 81, 84, 116 N.E. 782, 783 (1917) ; Cambell v. Third Dist. Comm. of Virginia State Bar, 179 Va. 244, 249, 18 S.E.2d 883, 885 (1942). Other cases speak in terms of rights. E.g., Ex parte Wall, 107 U.S. 265, 303 (1882) ; Woodward v. State Bar, 16 Cal. 2d 755, 757, 108 P.2d 407, 408 (1940); In re Metzenbaum, 22 Wash. 2d 75, 79, 154 P.2d 602,604 (1944). Essentially a person has the qualified right to practice law if he meets non-arbitrary and nondiscriminatory standards established for the protection of society. See, e.g., Ex parte Secombe, 60 U.S. (19 How.) 9, 13 (1856) ; Brents v. Stone, 60 F. Supp. 82, 84 (E.D. Ill. 1945) ; In re McDonald, 200 Ind. 424, 428, 164 N.E.2d 261, 262 (1928).

33. See cases cited note 32 supra. In the Slochower case, a teacher had been discharged by the City of New York solely for pleading the Fifth Amendment before a congressional committee. The Supreme Court said, "The problem of balancing the State's interest in the loyalty of those in its service with the traditional safeguards of individual rights is a continuing one. To state that a person does not have a constitutional right to government employment is only to say that he must comply with reasonable, lawful, and non-discriminatory terms laid down by the proper authorities .... Since no inference of guilt was possible from the claim before the federal committee, the discharge falls of its own weight as wholly without support." Hence, finding that pleading the Fifth Amendment forms no basis for inferring unfitness, the Supreme Court reversed Slochower's dismissal.

The "proper authority" to determine the fitness of applicants for admission to the bar is the court. See note 20 supra.

34. Most judicial statements concerning the lawyer's duty to clients have been made in a disciplinary rather than admission context. See Drinker, Legal ETHICs 89-18S (1953), where the author discusses in detail the various Canons of Professional Ethics of the American Bar Association relating to the lawyer-client relationship. While it is obvious in many disbarment proceedings that specific conduct has injured a client, this is never true in an admission proceeding. In the latter investigation the court must attempt to infer from 
process. ${ }^{35}$ These requirements stem from the peculiar position of a legal practitioner. Because of the technical nature of legal practice, a client may easily be deluded or defrauded by an unscrupulous attorney. Similarly, in his role in court a lawyer might obstruct the judicial process by devices ranging from misrepresentation of case holdings to bribery of jurors. ${ }^{36}$ Accordingly, past acts of an illegal or fraudulent nature may indicate potential danger to clients and courts which would justify denial of admission. Occasional mention is made of a third interest to be protected: the reputation of the bar. ${ }^{37}$ But this standard seems at best superfluous. Where an applicant's past or possible future acts might lead to widespread distrust of the professional conduct of attorneys, the bar would be adequately protected if the first two criteria were enforced. But if safeguarding the reputation of the bar were expanded to require attorney conformity to varying community standards of personal belief and decorum, the individual bar examiner would have a practically unlimited

prior nonprofessional acts the applicant's probable future behaviour. See REPORT on REaUIREMENTS FOR ADMisSION TO THE BAR 252-55.

35. Such conduct might include subornation of perjury, Paonessa v. State Bar, $43 \mathrm{Cal}$. $2 \mathrm{~d} 222,272$ P.2d 510 (1954) (suspension); threatening criminal action to force settlement of civil claim, In $r$ Dworkin, 16 N.J. 455, 109 A.2d 285 (1954) (same); intentionally deceiving opposing counsel, Coviello v. State Bar, 275 P.2d 482 (Cal. 1954) (same); introducing scandalous pleadings, In re Richter, 187 Wis. 490, 204 N.W. 492 (1925) (disbarment), and participating in lynching of the accused, Ex parte Wall, 107 U.S. 265 (1882) (same).

36. E.g., In re Keenan, 313 Mass. 186, 47 N.E.2d 12 (1943) (bribery of jurors); In re Greenberg, 15 N.J. 132, 104 A.2d 46 (1954) (misrepresentation) (dictum).

37. Protecting the profession's honor is often mentioned in disbarment proceedings as a reason for expelling certain attorneys. One of two rationalizations is usually stressed. Either public confidence in the profession, and thus in the administration of justice, is in danger of being undermined, e.g., State v. Wiebusch, $153 \mathrm{Neb} .583,594-95,45 \mathrm{~N} . \mathrm{W} .2 \mathrm{~d}$ 583, 589 (1951); In re H- S- 69 S.W.2d 325 (Mo. Ct. App. 1934); State v. Murrell, 74 So. 2d 221, 224 (Fla. 1954), or other members of the bar may suffer a loss of prestige because of professional association with the unethical attorney, e.g., Whitsitt v. Bar Rules Comm., 223 Arl. 860, 868-69, 269 S.W.2d 699, 703 (1954) ; State v. Sheiner, 6 Fla. Supp. 127, 136 (Cir. Ct. Dade County 1954), rev'd, S2 So. 2d 657 (Fla. 1955).

But in mast cases where these considerations have been invoked, protection of client and court justified disciplinary action in any event. State v. Wiebusch, supra (judge practicing in his own court); In re $\mathrm{H}-\mathrm{S}-$ _—, supra (bribing officials and solicitation); State v. Murrell, supra (solicitation); Whitsitt v. Bar Rules Comm., supra (extorting high fees). In only a few cases has disbarment been ordered for conduct which was harmful to neither client nor court but which was considered as reflecting so adversely on the reputation of the profession as to warrant punishment. See Grievance Comm. v. Broder, 112 Conn. 263, 152 At1. 292 (1930) (adultery). Contra, State v. Byrkett, 4 Ohio Dec. 89 (C.P. 1896). See also In re Arctander, 110 Wash. 296, 306, 188 Pac. 380, 383 (1920) (charging fees to selective service applicants for filling in their registration statements and representing an alien in proceedings to avoid draft call). But cf. In re Clifton, 33 Idaho 614, 196 Pac. 670 (1921), where the court refused to follow In re Arctander, supra.

In cases of admission, as opposed to disbarment, however, it is possible that a more general criterion must be used; there are no specific professional acts to point to as evidence of future incompetence or unscrupulousness. 
discretion to deny admission on subjective grounds. ${ }^{38}$ Undoubtedly, requiring a candidate for admission to show that his character satisfies the ethical standards of the profession is as justified as requiring him to demonstrate his professional learning. ${ }^{39}$ But the purpose of the requirement is one of qualification, not one of punishment. ${ }^{40}$ The analogy to the requirement of professional learning itself implies that "good moral character" must be determined by objective criteria designed to test the capacities required by the practice of law.

Schware's use of an assumed name in the thirties seems inadequate to support the required inference of a propensity to mislead either clients or the court. To form the basis of civil liability, use of an assumed name must be accompanied by intent to defraud or actual injury to another. ${ }^{41}$ But Schware had substituted an Italian name for a Jewish one solely for the purpose of seeking and maintaining employment and facilitating organizational activities for a union local representing predominantly Italian workers. ${ }^{42}$ Not only was there neither legal injury nor intent to defraud in these circumstances, but it is difficult to perceive even moral wrong-doing in masking religious identity to overcome the effects of prejudice. The court also stated that, despite resumption of his true name in 1940, Schware's present unrepentant attitude toward the use of aliases might indicate unfitness for practice as an attorney. ${ }^{43}$ But this conclusion seems improper. If assumption of an alias was not morally culpable at the time and under the circumstances in which it was done, it is difficult to perceive why the passage of time should render the act one for which the applicant must repent, or how nonrepentance could indicate that the applicant might use aliases for culpable purposes if, in 1955, he were admitted to practice.

Nor does the fact of prior arrests seem adequate to support denial of Schware's application. Under certain circumstances arrests not followed by indictment or even arraignment may indicate bad moral character. ${ }^{44}$ In many

38. E.g., In re Anastaplo, 3 IIl. 2d 471, 121 N.E.2d 826 (1954), appeal dismisscd, 348 U.S. 946 (1955) (denial of admission); see London, Heresy and The Illinois Bar: The Application of George Anastaplo for Admission, 12 LAw. Gund Rev. 163 (1952); Note, 50 Nw. U.L. Rev. 94 (1955) ; cf. State v. Sheiner, 6 Fla. Supp. 127 (Cir. Ct. Dade County 1954) (disbarment), rev'd, 82 So. $2 \mathrm{~d} 657$ (Fla. 1955).

39. In re Rouss, 221 N.Y. 81, 85, 116 N.E. 782, 783 (1917) ; see REPORT ON REQUIREMENTS FOR AdMrission to THE BAR 251.

40. It is constantly reiterated in discipline cases that the purpose of the proceeding is protection of the public and not punishment of the attorney. See, e.g., In re Joyce, 242 Minn. 427, 431, 65 N.W.2d 581, 583 (1954); In re Rouss, supra note 39; In re Steinberg, 44 Wash. 2d 707, 716, 269 P.2d 970, 974 (1954).

41. In re Liebowitz, 49 F. Supp. 953, 954 (N.D. Ill. 1943); United States v. McKay, 2 F.2d 257,259 (D. Nev. 1924); Reinken v. Reinken, 351 I11. 409, 413, 184 N.E. 639 , 640 (1933).

42. On one occasion, in 1934, Schware gave another assumed name to California police upon being arrested in connection with a maritime strike. Schware v. Board of Ear Examiners, 291 P.2d 607,612 (N.M. 1955). He testified to the Board that he used the alias because employers would not rehire him if his labor union activities came to their attention.

43. Id. at 617 . 
situations, however, arrest as such has no bearing on the ability of an applicant to maintain standards of professional ethics. For example, Schware was arrested on suspicion of driving a stolen vehicle, but released on ascertainment that the car was not in fact stolen; this arrest could have no bearing on his moral character. ${ }^{45}$ Likewise, in an era of turbulent labor relations, detentions followed by release without arraignment during a strike in which several thousand persons were similarly arrested can scarcely be taken as evidence of unfitness to practice as an attorney twenty years later. ${ }^{46}$ And it is difficult to understand how the court deduced, from Schware's explanation that several thousand others were similarly apprehended without charges being pressed, that his failure to repent for such arrests was improper. ${ }^{47}$

The nol-prossed indictment in 1940 seems equally irrelevant to Schware's fitness to become an attorney. Many courts recognize in disbarment proceedings that even conviction of a felony not involving moral turpitude is insufficient in itself to warrant expulsion. ${ }^{48}$ Similarly, in cases involving admission to the bar, conviction of a felony should not be regarded as conclusive of bad moral character unless the criminal conduct involved acts of "moral turpitude." 49 Yet the New Mexico Supreme Court in Schware indicated that even a nolprossed indictment for conduct which might possibly have supported a convic-

44. E.g., In re Stover, 65 Cal. App. 622, 224 Pac. 771 (1924); In re Vincent, 282 S.W.2d 335 (Ky. 1955) (indicted for assault but charges dropped).

Conviction clearly is not necessary to support denial of admission if the parties involved had at least behaved in a manner which reflected on their professional fitness. Application of Cassidy, 268 App. Div. 282, 51 N.Y.S.2d 202 (2d Dep't 1944). The same is true for disbarment. People v. Meyerovitz, 27S Ill. 356, 116 N.E. 189 (1917) ; In re Richards, 333 Mo. 907, 920-21, 63 S.W.2d 672, 678 (1933).

45. Schware v. Board of Bar Examiners, 291 P.2d 607, 613-14 (N.M. 1955).

46. For congressional criticism of the widespread arrests during the maritime and other strikes, see S. REP. No. 1150, 77th Cong., 2d Sess. 35, 119-24, 131, 512 (1942) ; S. REP. No. 398, 78th Cong., 2d Sess. 1373-75, 1519 (1944).

47. Schware v. Board of Bar Examiners, 291 P.2d 607, 617 (N.M. 1955).

48. Statutes in many jurisdictions provide for disbarment after conviction for a crime involving moral turpitude, making no distinction between felony and misdemeanor. See, c.g., Cal. Bus. \& Prof. Code $\$ 6106$ (1955); Md. Ann. Code Gen. Laws art. 10, § 12 (Cum. Supp. 1955) ; Mo. Ann. Stat. $\$ 484.190$ (Vernon 1949); Ohio Rev. Code Ann. $\$ 4705.02$ (Page 1954). In many states where the legislature has not stipulated the grounds, courts have reached the same result. E.g., In re Pontarelli, 393 Ill. 310, 313, 66 N.E.2d 83, 84 (1946) ; State ex rel. Wright v. Sowards, 134 Neb. 159, 161, 278 N.W. 148, 149 (1938).

On the other hand many statutes provide for disbarment after conviction of any felony. See, c.g., Ala. Code tit. 46, $\$ 49$ (1953) ; N.Y. Judiclary Law $\$ 90$; Wash. Rev. Code Awn. $\$ 2.48 .220$ (1951). And, without statute, some courts reach a similar result. E.g., In $r$ Welansky, 319 Mass. 205, 56 N.E.2d 202 (1946) (involuntary manslaughter); In re Gottesfield, 245 Pa. 314, 317, 91 Atl. 494, 495 (1914) (infamous crime).

49. See In $7 e$ Hyra, 15 N.J. 252, 256, 104 A.2d 609, 611 (1954) (Vanderbilt, C.J., dissenting) (larceny conviction discovered after admission should warrant disbarment because it was the type of conviction which would have resulted in denial of admission); In rc Rouss, 221 N.Y. $81,85,116$ N.E. 782,783 (1917). Statutes sometimes stipulate as a ground for disbarment conduct which would have precluded admission. E.g., ORE. Rev. STat. $\$ 9.470(1953)$. 
tion, but hardly could have evinced moral turpitude, reflected on the applicant's ability to meet the ethical standards of the legal profession. ${ }^{50}$ Schware was indicted for violating the Neutrality Act by volunteering, and urging others to volunteer, for the Spanish Loyalist army. The indictment was nol-prossed within ten days, and on the state of the record it seems doubtful that any crime actually was committed. ${ }^{51}$ Moreover, the undisputed testimony indicated that Schware was unaware at the time of the existence of the Act. ${ }^{52}$ To hold that these facts constitute evidence of unfitness to practice law in 1955 appears to extend the "good moral character" requirement beyond reason or logic, and to judge Schware on his political beliefs rather than his actions. For Schware's actions were not legally distinguishable from those of many Americans who. a short time later, joined, and urged others to join, British and Canadian forces. ${ }^{53}$ Differentiating today between the moral character of those who in 1939-1940 were willing to fight Hitler and those who were willing to fight Franco seems possible only on the basis of subjective political opinion. ${ }^{64}$ And employment of such criteria to ascertain fitness for the practice of law unwarrantedly places an applicant at the mercy of the political notions of a bar examiner.

Thus the court's decision can be defended, if at all, only if Schware's prior affiliation with the Communist Party is sufficient in itself to support an inference of bad moral character. While it has been held that present membership in organizations advocating illegal use of force is incompatible with the ethical standards of the legal profession ${ }^{55}$ and the lawyer's oath to support the state

50. Schware v. Board of Bar Examiners, 291 P.2d 607, 617 (N.M. 1955).

51. The majority and dissenting opinions on rehearing in Sclizure disagreed as to whether the applicant was vulnerable to conviction. Id. at 630-34. The statutory language was aimed at one who "hires or retains another to enlist," and there is some question whether urging recruitment would fit within that language, $C f$. Gayon v. McCarthy, 252 U.S. 171, 177 (1920). And even if a technical crime were committed, it is doubtful whether it suggested want of good character. See 86 Cong. REc. 1981-82 (1940), where Senator Norris comments adversely upon the large number of Neutrality Act arrests in Detroit at the time. In the only case where such violation was considered in relation to moral character, the court denied naturalization of an alien on other grounds. In re Addis, 252 Fed. 886 (N.D. Cal. 1918).

52. Schware v. Board of Bar Examiners, 291 P.2d 607, 620 (N.M. 1955).

53. No Neutrality Act arrest, indictment, conviction or appeal has been found in connection with those who joined or recruited for any country engaged in hostilities during World War II.

54. It is interesting to note the differences in opinion in the United States during the Spanish Civil War concerning support for the contending forces. Compare N.Y. Times, Jan. 16,1939 , p. 8 , col. 7 ; id., Feb. 27,1938 , p. 25 , col. 3 (various Catholic groups announcing support for Franco's rebels) with id., Jan. 24, 1939, p. 12, col. 2; id., March 13, 1938, $\S 4$, p. 8 , col. 7 (Protestant and Jewish groups and American educators announcing support for Loyalists).

55. In re Anastaplo, 3 Ill. 2d 471, 478-80, 121 N.E.2d 826, 830-31 (1954), appeal dismissed, 348 U.S. 946 (1955) (Communist Party) ; Konigsberg v. State Bar, supra note 19 (same); In re Smith, 133 Wash. 145, 233 Pac. 288 (1925) (I.W.W.) ; Martin v. Law Society, [1950] 3 D.L.R. 173 (B.C.C.A.) (Labour Progressive Party, Communist Party); 
or Federal Constitution, ${ }^{56}$ past membership in such organizations has never, standing alone, been deemed grounds for exclusion by any American court.57 And in the cases where admission was denied for present membership, the courts usually relied on conduct as well as organizational affiliation. recent decisions may appear to predicate exclusion solely on refusal to answer questions relating to present Communist Party membership, but in both cases the courts also relied on recent statements by the applicants indicating that their beliefs were inconsistent with the lawyer's oath. ${ }^{59}$ And in the only case where disbarment charges were based exclusively on an attorney's refusal to state whether or not he was presently a member of the Communist Party, the court held that such refusal did not constitute unethical conduct warranting expulsion. ${ }^{10}$ It has been strongly urged that recent cases in this area indicate

cf. Application of Cassidy, 268 App. Div. 282, 51 N.Y.S.2d 202 (2d Dep't 1944) (Christian Front).

The American Bar Association has urged disbarment of all attorneys presently found to be Communists. 7S A.B.A. REP. 439 (1953). A number of law review articles have taken the same position. See Comment, 2 U.C.L.A.L. Rev. 224, 228-33 (1955) ; Notes, 26 NorRe DaMie LAW. 498 (1951); 28 CAN. B. REv. 893, 899-900 (1950). But see Countryman, Loyalty Tests for Laziyers, 13 LAw. GundD Rev. 149 (1953) ; cf. Starrs, Considerations on Detcrmination of Good Moral Character, 18 U. DEr. L.J. 195, 219-20 (1955) ; Brown \& Fassett, Loyalty Tests for Admission to the Bar, 20 U. CHI. L. REv. 480, 501-02 (1953).

56. In $r e$ Anastaplo, supra note 55; Martin v. Law Society, supra note 55.

All states require an applicant to take an attorney's oath. Although the wording differs, an applicant usually must swear to ughold the state and federal constitutions. E.g., ARIz. Code Ann. \$ 32-101 (1939); Ill. Ann. Stat. c. 13, \$ 4 (Smith-Hurd 1951); PA. Stat. AnN. tit. 17, $\$ 1603$ (Purdon 1930).

57. Cf. Brown \& Fassett, supra note 55, at 502, where the authors cite answers to questionnaires revealing that past membership in the Communist Party was insufficient to bar applicants in two instances. See also cases cited note 58 infra.

58. In $r e$ Anastaplo, 3 I11. 2d 471, 121 N.E.2d 826 (1954), appeal dismissed, 348 U.S. 946 (1955) (refusal to answer questions; enunciated belief in right to revolution) ; Konigsberg v. State Bar, supra note 19 (newspaper articles, speeches); In re Smith, 133 Wash. 145, 233 Pac. 288 (1925) (speeches) ; Application of Cassidy, 268 App. Div. 282, 51 N.Y.S. 2d 202 (2d Dep't 1944) (same). Contra, Martin v. Law Society, [1950] 3 D.L.R. 173 (B.C.C.A.) (membership alone).

59. In re Anastaplo, supra note 58; Konigsberg v. State Bar, supra note 19. The Anastaplo decision has been soundly criticized in a number of articles. See London, supra note 38; Starrs, supra note 55, at 216, 223-24; Brown \& Fassett, supra note 55, at 502; Note, 50 Nw. U.L. REv. 94 (1955). But see Comment, 2 U.C.L.A.L. Rev. 224, 233 (1955).

60. Sheiner v. Florida, S2 So. 2d 657 (Fla. 1955), criticized 41 CoRnell L.Q. 304 (1956); cf. Welanko's Case, 99 N.H. 413, 112 A.2d 50 (1955). The Fifth Amendment question is the subject of a resolution of the American Bar Association urging disbarment for any attorney refusing to answer questions relating to Communism. 78 A.B.A. REP. 388-\$9 (1953). But cf. Brown, Lawyers and the Fifth Amendment: A Dissent, 40 A.B.A.J. 404 (1954).

Although Welanko's Case is cited in support of the ABA position, see, e.g., Bar Association's Annual Mecting, 24 U.S.L. WEEK 2100, 2106 (Aug. 30, 1955), it is clearly distinguishable. There, an attorney who was summoned to appear before the New Hampshire Supreme Court pursuant to an investigation of his alleged Communist Party membership not only failed in any way to answer charges, but did not even put in an appearance in response to the court's order, and was consequently suspended. 
an undesirable trend toward requiring applicants to meet undefined standards of loyalty varying with the political beliefs of individual bar examiners. ${ }^{01}$ It has also been contended that even present membership in the Communist Party does not support a permissible inference of danger to client and court justifying exclusion from the legal profession. ${ }^{62}$ Whatever opposition there may be to these views, no court has ever held that past membership in an organization recently held to be illegal is alone sufficient to indicate either bad moral character or present disloyalty. Certainly no unfavorable inference concerning an applicant's moral fitness to serve client and court can properly be drawn where, as in Schware, the organization was legal during the period of membership and there is a repudiation of long standing. ${ }^{63}$

If, as would appear from the foregoing analysis, those instances of past conduct used as criteria to determine Schware's present character do not reasonably reflect on his ability to serve client and court, the denial of admission raises serious due process questions. Both procedural and substantive due process of law have been held applicable to cases concerning exclusion from various callings. ${ }^{64}$ It may scarcely be doubted that application of completely

61. Conference Working Group, The Independence of the Bar, $13 \mathrm{LAw}$. GuILD REv. 158, 171 (1953); Brown \& Fassett, supra note 55, at 501-04.

See also Brief of Petitioner on Petition for Writ of Certiorari to the United States Supreme Court, pp. 15-22, Konigsberg v. State Bar, supra note 19, urging this alleged trend and its effect on the independence of the bar as strong reasons for granting review.

62. Countryman, supra note 55.

Discussion of admissibility to the bar of proven present Communists is academic if membership in the Communist Party, with knowledge of its illegal aims, is a crime. It has been so considered in United States v. Lightfoot, 228 F.2d 861 (7th Cir. 1956), cert. granted, 24 U.S.L. WeEk 3252 (U.S. March 27, 1956) (No. 661) ; Seales v. United States, 227 F.2d 581 (4th Cir. 1955), cert. granted, 24 U.S.L. WEEK 3252 (U.S. March 27, 1956) (No. 626) ; Frankfeld v. United States, 198 F.2d 679, 683-84 (4th Cir. 1952) (dictum), cert. denied, 344 U.S. 922 (1953). A Smith Act conviction has been held to warrant disbarment. Braverman v. Baltimore City Bar Ass'n, 24 U.S.L. WeEK 2437 (Md. Ct. App. March 13, 1956). Since conviction for criminal conduct is not necessary to warrant disbarment or denial of admission, present Communists could be denied admission for present and continuing commission of a criminal act. And once a criminal stigma attaches to membership in the Party it seems likely in any event that courts will hold, with the Braverman court, that such conduct involves moral turpitude. See note 48 supra.

63. The majority assumed without deciding that membership in the Communist Party from 1932 until 1940 was legal. Schware v. Board of Bar Examiners, 291 P.2d 607, 609 (N.M. 1955). On Schware's repudiation, see notes 29 and 30 stpra.

64. In the case of $1 n$ re Carter, 192 F.2d 15 (D.C. Cir. 1951), the court held that an application to carry on a bail bonding business (which the court analogized to an attorney's application, id. at 16-17) could not be denied without a hearing, and that a hearing involved more than an arbitrary and purely administrative refusal to renew or grant a license. $B u t$ cf. Brooks v. Laws, 208 F.2d 18 (D.C. Cir. 1953), where the court held that the District Admission Committee's failure to recommend an applicant to the bar and the district court's letter informing the applicant of the refusal was not a final decision so that review was impossible.

Substantive due process claims have been upheld in a number of similar cases. Wieman v. Updegraff, 344 U.S. 183 (1952) (teacher); Smith v. Texas, 233 U.S. 630 (1914) (train 
arbitrary standards, such as race and religion, as tests of moral fitness for admission to the bar, would violate due process. ${ }^{65}$ While under certain circumstances the four categories of conduct considered by the court in Schware could be deemed relevant in predicting potential danger to client and court, when the facts on which this denial of admission was predicated are closely scrutinized it may seriously be questioned whether the inferences drawn were not so unjustifiable as to render the denial arbitrary. ${ }^{66}$ And though the constitutional prohibition against ex post facto laws does not seem technically applicable, ${ }^{67}$ the fact that the court retrospectively applied present conceptions of propriety to past acts, without considering them in the context of the time of their occurrence, strengthens the conclusion that the denial of admission was fundamentally unfair.

conductor); State v. Armstrong, 38 Idaho 493, 225 Pac. 491 (1923) (chiropodist) ; Noel v. People, 187 I11. 587, 58 N.E. 616 (1900) (drug sellers); Wyeth v. Board of Health, 200 Mass. 474, 86 N.E. 925 (1909) (embalmer) ; People v. Ringe, 125 App. Div. 592, 110 N.Y. Supp. 74 (2d Dep't 1908) (same) ; see Note, Pozver of State to Restrict One's Right to Estgage in Lazoful Occupation, 25 VA. L. REv. 219 (1938). See also Schactman v. Dulles, 225 F.2d 938 (D.C. Cir. 1955) (granting or withholding of passport must be based on reasonable standards). In a number of cases courts have upheld restrictive standards only after finding them neither arbitrary nor unreasonable. E.g., Dent v. West Virginia, 129 U.S. 114, $121-22$ (1889) (doctor); Ex parte Secombe, 60 U.S. 9, 13 (1856) (lawyer); Brents v. Stone, 60 F. Supp. 82, 84 (E.D. Ill. 1945) (lawyer).

For procedural due process cases see note 11 supra.

65. In rc Summers, 325 U.S. 561, 571 (1945) (dictum); id. at 575 (dissent). But cf. Bradwell v. State, 83 U.S. (16 Wall.) 130 (1872) (denying a woman's request for admission to the bar, and rejecting her argument that practice of law is one of the "privileges and immunities" of United States citizenship).

66. See notes $43,46,53,63$ supra and accompanying text.

67. In order for the ex post facto prohibition, U.S. Const. art. I, $\$ 10$, cl. 1, to apply, the exclusion must be considered to constitute "punishment" for conduct which was legal at the time of its occurrence. See McAllister, Ex Post Facto Laws in the Supreme Court of the United States, 15 CALrF. L. Rev. 269 (1927). And the Supreme Court has been unwilling in recent years to hold that deprivations which are "civil" in form are nevertheless "penal" in character. See, e.g., Garner v. Board of Public Works, 341 U.S. 716 (1951). Compare E.x parte Garland, 71 U.S. (4 Wall.) 333 (1866) ; Cummings v. Missouri, 71 U.S. (4 Wall.) 277 (1866) ; United States v. Lovett, 328 U.S. 303 (1946). In any event the conclusion that the deprivation imposed in Schware was so unrelated to qualifications for admission as to constitute "punishment" would make the decision unconstitutional as a denial of due process, wholly apart from its ex post facto nature. Cf. Comment, 64 Yale L.J. 1164, 1182 n.100 (1955); notes 32, 33, 40 supra and accompanying text.

An even more serious stumbling block than the "punishment" concept is the supposed inapplicability of the ex post facto clause to judicial action. In Ross v. Oregon, 227 U.S. 150 (1913), the Supreme Court announced that a state court's construction of a criminal statute to include conduct previously thought to be immune was not within the purview of the constitutional provision. Since New Mexico required good moral character as a prerequisite for admission during the period of Schware's legal membership in the Communist Party, it would therefore be impossible to characterize the law as ex post facto. The only question open for decision, therefore, is whether the court's interpretation and application of the law was consistent with the requirements of due process. 
Furthermore, if the New Mexico court relied upon Schware's political beliefs to infer moral unfitness for the practice of law, it would also appear that his constitutional rights of free speech and assembly were abridged. As the dissent points out, there is almost nothing in the record apart from the applicant's political beliefs on which to base a denial of admission. ${ }^{08}$ Once it is determined that these opinions cannot support an inference of moral unfitness, and since they do not relate to any other requirement for admission, the denial amounts to an exclusion simply for holding these opinions. ${ }^{69}$ And if these political beliefs fall under the aegis of the constitutional protection of free speech and assembly, the court would seem to be requiring a surrender of constitutional rights as a condition for admission to the bar. ${ }^{70}$ Even the granting of a "privilege" cannot be so conditioned. ${ }^{71}$

68. Schware v. Board of Bar Examiners, 291 P.2d 607, 629 (N.M. 1955) (dissenting opinion).

69. Schware's ability to take the New Mexico attorney's oath to support the state and federal constitutions, Rules Governing Admission to the Bar of the State of NLw Mexico rule 5, N.M. Stat. Ann., following $\$ 18-1-8$, at p. 88 (1953), can either be considered subsumed under the good moral character requirement or be considered as a separate requirement. The court did not suggest that Schware was unable to take this oath in good faith as had been done in In re Anastaplo, 3 I11. 2d 471, 121 N.E.2d 826 (1954), appcal dismissed, 348 U.S. 946 (1955). Such a finding in the face of Schware's statements and the lack of any proof of present Communist affiliation would have been more difficult to justify than the finding of questionable moral character.

70. Of the recent Supreme Court decisions involving the disqualification of certain persons from areas of public and private employment because of their political beliefs, only American Communications Ass'n v. Douds, 339 U.S. 382 (1950), and Adler v. Board of Education, 342 U.S. 485 (1952), specifically decided on the applicability of the First Amendment. In neither case was any doubt expressed that the deprivation of employment by state or federal government had to be examined in relation to the constitutional prohibition against abridgements of free speech. In both Douds and Adler the Court held the government action involved not prohibited by the First Amendment, finding a reasonable relationship between belief in the overthrow of the government by force and violence and a specific danger to society which a legislature could constitutionally attempt to prevent. The evil in Douds was political strikes, while in Adler it was inculcation in school children of false ideologies. If, however, no reasonable inference can be drawn from the political beliefs in question indicating that they will adversely affect the applicant's professional conduct, and these beliefs nonetheless are made the basis of exclusion from a calling, it would appear that the beliefs as such are being penalized, and that the First Amendment is violated. Compare In re Summers, 325 U.S. 561 (1945).

71. See cases cited note 32 supra. 